\title{
Perbandingan Pengetahuan dengan Sikap dalam Pencegahan Demam Berdarah Dengue di Daerah Urban dan Rural
}

\author{
Titik Respati, Budiman, Fajar A Yulianto, Eka Nurhayati, Yudi Feriandri \\ Fakultas Kedokteran Universitas Islam Bandung
}

\begin{abstract}
Abstrak
Demam berdarah dengue tidak saja menimbulkan beban penyakit, akan tetapi juga beban ekonomi yang tinggi bagi individu, keluarga maupun negara. Belum terdapat obat atau vaksin yang efektif telah membatasi pilihan dalam melakukan pencegahan dan pengobatan. Program yang dilaksanakan adalah vektor kontrol untuk membatasi transmisi virus yang memerlukan peran serta masyarakat secara terus menerus. Penelitian ini bertujuan mengetahui perbedaan persepsi tentang penyakit dengan praktik dalam pencegahan demam berdarah di daerah urban (Tamansari) dan daerah rural (Ciparay). Penelitian dilakukan pada total 208 responden di Tamansari Bandung dan 122 responden di Ciparay pada bulan Februari sampai Maret 2015. Hasil penelitian menunjukkan bahwa kondisi lingkungan di kedua daerah belum baik dengan sanitasi dasar terutama sistem pembuangan air limbah yang belum memadai. Perbedaan tampak dalam hubungan antara persepsi mengenai demam berdarah dan sikap dalam praktik pencegahan. Di Tamansari persepsi mengenai demam berdarah dengue berhubungan dengan sikap dalam memberantas sarang nyamuk (OR 14,297; p<0,05). Ciparay menunjukkan fenomena yang berlawanan, persepsi mengenai demam berdarah dengue tidak berhubungan dengan sikap dalam pemberantasan sarang nyamuk (OR o,327; p>0,05). Simpulan, terdapat perbedaan persepsi dengan praktik pencegahan demam berdarah dengue antara responden Tamansari dan Ciparay.
\end{abstract}

Kata kunci: Demam berdarah, persepsi, sikap, urban dan rural

\section{Comparison on Knowledge, Attitude and Practice Regarding Dengue Prevention in Urban and Rural Area}

\begin{abstract}
Dengue fever is not only become a burden of disease but can also become burden on economy affected individual person, family and country. At present there weren't any specific drug and no effective vaccine yet, that the prevention was limited to disease prevention through disease management and vector control which needed continuing community participation. This study aims to understand the difference between perception and the practice in vector control activities between urban and rural areas. Data was collected using questionnaires from 208 and 122 respondents from Tamansari dan Ciparay respectively since February to March 2015. Results showed that the environment condition in both study area were not good especially for the basic sanitation facilities. There were differences between perception of the disease and the practice of vector control in these two areas. Perception of the disease associate with practice in vector control in Tamansari was OR 14.297, $\mathrm{p}<0.05$ while it was the other way in Ciparay was OR $0.327, p>0.05$. In conclusion there are differences between Tamansari and Ciparay regarding perception of dengue fever with the practice on vector control.
\end{abstract}

Key words: Dengue fever, perception, practice, urban and rural 


\section{Pendahuluan}

Dalam periode 50 tahun terakhir ini kejadian demam berdarah dengue (DBD) meningkat 30 kali lipat di seluruh dunia. Penduduk dunia yang rentan berjumlah 50\% dari total penduduk, yaitu sekitar 3 miliar orang dengan insidensi sebanyak 50-100 juta per tahun. Kota Bandung menjadi kota dengan angka kejadian DBD paling tinggi di Jawa Barat. Terdapat sebanyak 3.901, 5.096, 5.736, dan 3.132 kasus pada tahun 2011, 2012, 2013, dan 2014 secara berurutan. ${ }^{1}$

Demam berdarah dengue (DBD) tidak saja menimbulkan beban karena penyakit ini, akan tetapi juga beban ekonomi yang tinggi terhadap individu, keluarga, maupun negara. Sampai saat ini belum ada obat atau vaksin yang efektif telah membatasi pilihan dalam hal melakukan pencegahan dan juga pengobatan. ${ }^{2}$ Program yang selama ini dilakukan adalah memperbaiki manajemen kasus untuk mencegah kematian dan vektor kontrol dalam upaya untuk membatasi transmisi virus. ${ }^{3}$ Program ini membutuhkan partispasi dari masyarakat yang terus menerus dalam pemeliharaan lingkungan rumah serta sekitar pemukiman mereka.

Selama belum ada obat-obatan yang dapat menjadi standar pengobatan dan belum tersedia vaksin yang dapat dipergunakan karena masih dalam tahap uji klinis maka pencegahan DBD dilakukan melalui upaya mengurangi sumber transmisi. Di Indonesia secara umum upaya pemberantasan sarang nyamuk (PSN) merupakan aktivitas utama upaya pencegahan DBD yang melibatkan peran serta dari seluruh masyarakat. Program ini sudah dilaksanakan sejak tahun 1992 dengan gerakan 3M, terdiri atas Menguras-Menutup-Mengubur. Gerakan 3M pada tahun 2000 tsudah dikembangkan menjadi 3M Plus dengan tambahan penggunaan larvasida, memelihara ikan dalam kolam, dan mencegah dari gigitan nyamuk. Sampai saat ini upaya untuk memberdayakan masyarakat tersebut belum dapat menunjukkan hasil yang diinginkan terutama dalam mengubah perilaku masyarakat untuk dapat secara terus menerus melakukan pemberantasan sarang nyamuk. ${ }^{4}$

Pengetahuan yang memadai mengenai DBD dan metode untuk mencegahnya harus dapat dimengerti oleh masyarakat sebelum mereka mau berpartisipasi aktif. ${ }^{5-7}$

Keberadaan individu atau sekelompok kecil yang mempunyai komitmen serta berdedikasi terhadap keberhasilan suatu program akan menjadi faktor yang akan lebih menentukan bila dibandingkan dengan suatu komite yang besar. $^{8-10}$ Persepsi mengenai penyakit sangat memengaruhi keterlibatan peranan masyarakat. Kondisi miskin dan kemiskinan menjadi suatu kendala karena DBD dianggap sebagai atribut orang miskin.

Faktor malas dan juga kondisi apatis yang dianggap sebagai sikap orang yang miskin telah terbukti merupakan satu kendala di Meksiko. ${ }^{11,12}$ Suatu penelitian lain yang dilakukan di Indonesia menunjukkan persepsi orang terhadap nyamuk adalah dianggap sebagai pengganggu dan bukan penyebab penyakit memengaruhi keterlibatan dalam aktivitas PSN. ${ }^{6}$

Penelitian ini untuk membandingkan tingkat pengetahuan dan sikap antara daerah urban dan daerah rural untuk mengetahui apakah terdapat hubungan tingkat pengetahuan dengan sikap dalam pencegahan dan pemberantasan demam berdarah dengue.

\section{Metode}

Penelitian untuk daerah urban dilaksanakan di Kota Bandung yang memiliki luas area 16.730 hektar dengan jumlah penduduk sebanyak 2.461.931 orang pada tahun 2012. ${ }^{13}$ Kecamatan Bandung Wetan di Tamansari telah terpilih sebagai daerah penelitian oleh karena termasuk dalam kawasan kumuh padat. Daerah rural Ciparay dipilih sebagai daerah rural yang berada sekitar $30 \mathrm{~km}$ dari Kota Bandung. Kecamatan ini termasuk ke dalam wilayah di Kabupaten Bandung Barat yang tercatat mempunyai jumlah penduduk sebanyak 3.470.393 dengan luas wilayah sebesar $1.762 \mathrm{~km}^{2} .{ }^{14}$ Pengambilan data dilakukan pada bulan Februari-Maret tahun 2015 oleh enumerator Poltekes Bandung dari Jurusan Kesehatan Lingkungan dan mahasiswa Fakultas Kedokteran (FK) Universitas Islam Bandung (Unisba) yang bekerja dalam tim 2 (dua) orang. Sebelum survei dilakukan terlebih dahulu diberikan pelatihan. Data dikumpulkan menggunakan alat bantu berupa kuesioner untuk survei rumah tangga. Sebelum pengambilan data itu dilaksanakan, semua penghuni rumah yang usianya telah dewasa diminta keikutsertaannya dalam penelitian dan bila telah setuju diminta untuk menandatangani lembar persetujuannya (inform consent). Kuesioner yang dipergunakan itu berisikan pertanyaan pengetahuan mengenai 
demam berdarah, persepsi dan juga sikap dalam pencegahan penyakit ini, serta aktivitas yang dilakukan untuk dapat mencegahnya. Kuesioner tersebut telah divalidasi dan disempurnakan sebelum akan dipergunakan. Responden yang terpilih adalah anggota keluarga yang telah dewasa (berusia lebih dari 17 tahun) yang berada di rumah tersebut pada saat penelitian itu dilaksanakan. Jumlah responden di daerah urban (Tamansari) dan rural (Ciparay) sebanyak 208 dan 122 orang masing-masing.

Analisis data penelitian dilaksanakan memakai Microsoft Excell 2007 dan juga SPSS versi 17.0. Chi-kuadrat dipergunakan untuk dapat menentukan hubungan variabel demografinya dan juga pengetahuan dengan sikap mengenai demam berdarah dengue. Variabel yang terbukti berpengaruh secara signifikan $(\mathrm{p} \leq 0,05)$ dalam

Tabel 1 Karakteristik Responden di Tamansari dan Ciparay

\begin{tabular}{|c|c|c|c|c|}
\hline & $\begin{array}{c}\text { Tamansari } \\
(\mathrm{n}=\mathbf{2 0 8})\end{array}$ & & $\begin{array}{l}\text { Ciparay } \\
(n=122)\end{array}$ & \\
\hline & Frekuensi & $\%$ & Frekuensi & $\%$ \\
\hline \multicolumn{5}{|l|}{ Jenis kelamin } \\
\hline Laki-laki & 52 & 25,0 & 23 & 18,9 \\
\hline Perempuan & 156 & 75,0 & 99 & 81 \\
\hline \multicolumn{5}{|l|}{ Usia (tahun) } \\
\hline$\leq 20$ & 4 & 1,9 & 3 & 2,4 \\
\hline $21-30$ & 29 & 13,9 & 20 & 16,4 \\
\hline $31-40$ & 48 & 23,1 & 28 & 23 \\
\hline $41-50$ & 60 & 28,8 & 41 & 33,6 \\
\hline $51-60$ & 39 & 18,8 & 23 & 18,9 \\
\hline$>50$ & 28 & 13,5 & 7 & 5,7 \\
\hline \multicolumn{5}{|l|}{ Pendidikan } \\
\hline SD & 49 & 23,6 & 32 & 26,2 \\
\hline SMP & 62 & 79,5 & 53 & 43,4 \\
\hline SMA & 78 & 37,5 & 33 & 27,7 \\
\hline Perguruan Tinggi & 19 & 9,1 & 4 & 3,3 \\
\hline \multicolumn{5}{|l|}{ Pendapatan } \\
\hline$<\mathrm{UMR}$ & 100 & 48,1 & 113 & 92,6 \\
\hline$\geq \mathrm{UMR}$ & 108 & 51,9 & 9 & 7,4 \\
\hline \multicolumn{5}{|l|}{ Pekerjaan } \\
\hline PNS & 6 & 2,9 & 2 & 1,7 \\
\hline Karyawan swasta & 16 & 7,7 & 10 & 8,2 \\
\hline Wirausaha & 48 & 23,1 & 27 & 22,1 \\
\hline Buruh & 13 & 6,3 & 21 & 17,2 \\
\hline Tidak bekerja & 125 & 60,0 & 62 & 50,8 \\
\hline
\end{tabular}


Tabel 2 Aktivitas Pencegahan Demam Berdarah Dengue di Tamansari dan Ciparay

\begin{tabular}{lccc}
\hline \multicolumn{1}{c}{ Aktivitas } & P Nilai & OR & 95\% \\
\hline Mengubur barang bekas yang dapat menampung air & $0,003^{*}$ & 2,018 & $1,271-3,203$ \\
Menutup wadah air & 0,139 & 1,406 & $0,894-2,211$ \\
Menguras wadah air & $0,001^{*}$ & 2,269 & $1,396-3,687$ \\
Menaburkan bubuk abate ke dalam wadah air & 0,739 & 1,083 & $0,678-1,731$ \\
Menyemprotkan insektisida & 0,954 & 1,014 & $0,622-1,655$ \\
Memelihara ikan dalam bak air & $0,014^{*}$ & 4,184 & $1,217-14,389$ \\
\hline
\end{tabular}

analisis bivariat dianalisis dengan menggunakan analisis OR (odds ratio) untuk dapat mengetahui perbandingan antara kedua daerah tersebut.

\section{Hasil}

Daerah penelitian di wilayah urban Tamansari merupakan daerah yang sangat padat di tengah Kota Bandung. Kebanyakan rumah dihuni oleh keluarga besar (kepala keluarga, istri, anak beserta mantu dan cucu). Rumah dengan jumlah penghuni sebanyak 10-20 orang merupakan hal yang biasa ditemukan, jumlah rata-rata penghuni sebanyak 6 orang.

Sumber utama air bersih berasal dari sumur (80\%) dan air hujan (20\%). Lebih dari 90\% rumah tidak mempunyai saluran pembuangan air limbah (SPAL) sehingga air limbah langsung dialirkan ke dalam sungai Cikapundung. Sampah rumah tangga telah mendapat perlakuan yang cukup baik dengan fasilitas pengangkutan sampah oleh petugas yang dilakukan setiap hari.

Daerah rural di Kecamatan Ciparay merupakan area pertanian dan perkebunan dengan klaster pemukiman penduduk yang tersebar. Di dalam klaster pemukiman itu terdapat variasi letak rumah, sebagian merupakan klaster pemukiman yang padat dan sebagian yang lain klaster pemukiman dengan kebun atau sawah di antara rumah penduduk. Jumlah penghuni rumah 5 (lima) orang dengan maksimal 12 orang dalam satu rumah.

Sumber air utama berasal dari PAM dan sumur. Fasilitas untuk saluran pembuangan limbah masih sangat terbatas dan sebagian besar sampah langsung di buang ke selokan atau sungai. Sampah padat sebagian langsung dibuang ke dalam tempat pembuangan sampah sementara, walaupun tempat tersebut bukan tempat untuk pembuangan sampah sementara yang resmi.

Responden kedua daerah rural dan urban itu kebanyakan adalah ibu rumah tangga yang berusia antara 20-50 tahun. Tingkat pendidikan responden adalah pendidikan dasar dengan pendapatan keluarga rata-rata di bawah Upah Minimum Regional (UMR) baik untuk Kota maupun Kabupaten Bandung.

Tabel di atas menunjukkan aktivitas yang biasa dilalukan di masing-masing daerah. Di Tamansari masyarakat 2 (dua) kali lebih sering melakukan kegiatan mengubur dan menguras wadah air jika dibanding dengan di Ciparay. Memelihara ikan di dalam bak air 4 kali lebih

Tabel 3 Persepsi Mengenai Demam Berdarah Dengue di Tamansari dan Ciparay

\begin{tabular}{|c|c|c|c|c|}
\hline \multirow{2}{*}{ Pernyataan } & \multicolumn{2}{|c|}{ Tamansari } & \multicolumn{2}{|c|}{ Ciparay } \\
\hline & $\mathbf{Y a}$ & Tidak & Ya & Tidak \\
\hline $\begin{array}{l}\text { Risiko keluarga tertular demam berdarah } \\
\text { tinggi }\end{array}$ & 94 & 62 & 31 & 90 \\
\hline $\begin{array}{l}\text { Demam berdarah dapat membebani keuangan } \\
\text { keluarga }\end{array}$ & 138 & 18 & 102 & 20 \\
\hline Demam berdarah dapat mengancam nyawa & 152 & 4 & 113 & 9 \\
\hline $\begin{array}{l}\text { Program pemberantasan nyamuk akan } \\
\text { bermanfaat bagi keluarga dan masyarakat }\end{array}$ & 149 & 7 & 116 & 6 \\
\hline $\begin{array}{l}\text { Aktivitas pemberantasan jentik dapat } \\
\text { dilakukan secara rutin }\end{array}$ & 117 & 39 & 99 & 23 \\
\hline
\end{tabular}




\begin{tabular}{|c|c|c|c|c|}
\hline \multirow{2}{*}{$\begin{array}{c}\text { Sikap Pencegahan Demam } \\
\text { Berdarah Dengue }\end{array}$} & \multicolumn{2}{|c|}{ Tamansari } & \multicolumn{2}{|c|}{ Ciparay } \\
\hline & Setuju & Tidak Setuju & Setuju & Tidak Setuju \\
\hline $\begin{array}{l}\text { Mengubur barang bekas yang dapat } \\
\text { menampung air }\end{array}$ & 102 & 55 & 111 & 10 \\
\hline Menutup wadah air & 136 & 21 & 119 & 3 \\
\hline Menguras wadah air & 150 & 7 & 121 & 1 \\
\hline $\begin{array}{l}\text { Menaburkan bubuk abate ke dalam } \\
\text { wadah air }\end{array}$ & 105 & 51 & 115 & 7 \\
\hline $\begin{array}{l}\text { Menyemprotkan insektisida } \\
\text { (fogging) }\end{array}$ & 96 & 59 & 112 & 10 \\
\hline Memelihara Ikan dalam bak air & 49 & 107 & 70 & 52 \\
\hline
\end{tabular}

banyak dilakukan di Tamansari.

Masyarakat memiliki persepsi mengenai demam berdarah dengue (DBD) yang bervariasi. Persepsi ini bergantung pada pendidikan dan pengalaman terhadap demam berdarah.

Tampaknya bahwa masyarakat yang tinggal di daerah urban Tamansari persepsi mengenai demam berdarah dengue mempunyai hubungan dengan sikap dalam hal memberantas sarang nyamuk (nilai OR 14,297; dan p<0,05). Daerah rural Ciparay menunjukkan fenomena yang berlawanan, di sini persepsi mengenai demam berdarah dengue tidak berhubungan dengan sikap dalam pemberantasan sarang nyamuk (OR o,327; p>0,05).

\section{Pembahasan}

Dalam penelitian hasilnya mayoritas responden adalah perempuan, yaitu sebesar $75 \%$ di daerah Tamansari dan $81 \%$ di daerah Ciparay. Di banyak wilayah, pada kenyataannya perempuan merupakan pemeran utama dalam memelihara kesehatan keluarganya dan juga lingkungan di daerah sekitarnya. Upaya untuk pemberantasan penyakit berupa upaya pencegahan, pengobatan, maupun upaya rehabilitasi selalu melibatkan perempuan, khususnya ibu rumah tangga. Di masyarakat, perempuan khususnya ibu rumah tangga diposisikan sebagai care giver yang akan bertugas menjaga, merawat, dan mengobati anggota keluarga apabila menderita sakit. Tugas ganda bahkan tugas multipel seorang ibu rumah tangga yang bekerja membuat sangatlah tidak mudah untuk mencegah penyakit. Tugas untuk menjaga kesehatan keluarga serta masyarakat tentu memerlukan waktu, tenaga, uang, serta dalam keterampilan.

Keterampilan untuk perawatan kesehatan keluarga dipengaruhi oleh pengetahuan dan juga pengalaman seseorang. Mereka yang memiliki banyak pengetahuan tentun akan lebih terampil daripada mereka yang pengetahuannya kurang. ${ }^{6}$ Sebuah penelitian di negara Mexico menyatakan bahwa rumah tangga dengan kepala keluarga perempuan mengakumulasi kontainer tempat air lebih banyak bila dibanding rumah tangga dengan kepala keluarganya laki-laki. ${ }^{12}$ Persoalan gender tersebut menjadi isu yang sangat penting dalam program pencegahan dan pemberantasan demam berdarah. Ketidakseimbangan antara peran perempuan dan laki-laki dalam program pencegahan demam berdarah dapat menjadi penyebab tidak berjalannya program secara baik dan berkesinambungan.

Persepsi dari masyarakat di kedua daerah tersebut mengenai demam berdarah dengue itu menunjukkan perbedaan. Penelitian yang telah dilakukan di Indonesia mengenai pengalaman ibu rumah tangga terhadap demam berdarah

Tabel 5 Perbedaan dalam Persepsi Mengenai Dengue dan Sikap dalam Pencegahan di Tamansari dan Ciparay

\begin{tabular}{lccc}
\hline & Nilai p & OR & IK 95\% \\
\hline Tamansari & 0,000 & 14,297 & $5 \cdot 942-34.401$ \\
Ciparay & 0,327 & 0,614 & $0.230-1.641$ \\
\hline
\end{tabular}


menyatakan bahwa pengalaman dari individu biasanya akan mampu membentuk pengalaman komunal yang dianggap lebih kuat terutama dalam masyarakat tradisional. ${ }^{6}$

Mengingat bahwa transmisinya penyakit DBD masih banyak kejadiannya di rumah maka keberhasilan program pencegahan dan juga pemberantasan demam berdarah dengue (DBD) sangat bergantung pada partisipasi masyarakat. Mayoritas dari responden menyatakan bahwa mengubur barang-barang yang bekas pakai yang dapat menampung air, serta menutup dan menguras wadah air adalah aktivitas yang penting dalam pencegahan demam berdarah dengue. Hasil seperti ini menunjukkan bahwa kampanye 3M cukup berhasil diterima oleh kalangan masyarakat baik masyarakat urban maupun rural. ${ }^{4}$ Beberapa penulis menyatakan bahwa keberhasilan suatu kampanye program belum menjadi tolok ukur keberhasilan program tersebut. Keberhasilannya program pencegahan DBD tersebut bergantung pada cara masyarakat memandang nyamuk sebagai penyebab DBD serta juga memahami betapa pentingnya upaya pelaksanaan dalam hal Pemberantasan Sarang Nyamuk (PSN) itu dilaksanakan di lingkungan masing-masing, terutama dengan cara langkahlangkah $3 \mathrm{M}$ plus yang benar. Beberapa studi telah memperlihatkan keberhasilan penerapan pendidikan kesehatan melalui sintesis dari faktor sosial budaya di masyarakat.

Masyarakat pada saat ini lebih cenderung menjadikan vektor kontrol sebagai tanggung jawab pemerintah saja. Komunikasi yang lebih baik harus dibangun agar masyarakat menyadari bahwa penyakit demam berdarah kemungkinan besar dapat terjadi dalam rumah dan lingkungan tempat tinggal mereka. Praktik pencegahan harus dilakukan oleh individu masing-masing dan juga masyarakat secara bersama karena pemerintah hanya mempunyai wewenang yang terbatas untuk masuk dalam area pribadi.

Persepsi tentang demam berdarah dengue dapat mengancam nyawa kita dan menyebabkan kesulitan yang lain seperti kesulitan keuangan telah diakui oleh mayoritas responden di kedua daerah penelitian tersebut. Meskipun demikian, sikap mereka dalam pencegahan penyakit ini menunjukkan perbedaan antara kedua daerah. Masyarakat di Tamansari menunjukkan sikap yang sesuai dengan persepsi mereka tentang penyakit, sedangkan masyarakat di Ciparay tidak menunjukkan sikap yang sesuai dengan persepsi mereka tentang demam berdarah dengue. Perbedaan ini dapat terjadi disebabkan karena pengertian di masyarakat mengenai hubungan lingkungan dengan demam berdarah belum memadai. Masih sangat dibutuhkan tempat penampungan persediaan air di sebagian besar rumah responden yang mampu menyebabkan peningkatan risiko tempat perindukan nyamuk.

Penggunaan tempat penampungan air tanpa disertai dengan manajemen tempat air yang memadai menjadi potensi terjadinya penyakit. Selain itu, sistem pembuangan limbah cair rumah tangga belum tersedia secara memadai, hal ini akan menyebabkan potensi bertambahnya perindukan nyamuk pula. Sampah padat yang tidak dikelola dengan baik tentu dapat menjadi salah satu tempat perkembangbiakan yang baik karena banyaknya material yang tergenang air. Sistem pembuangan sampah baik berupa sampah cair maupun sampah padat sangat diperlukan di kedua tempat agar program pencegahan serta pemberantasan demam berdarah dengue dapat berjalan dengan lebih baik. Penanganan masalah penyakit akibat lingkungan sangat bergantung pula pada tersedianya fasilitas dan sarana lingkungan terutama air bersih dan sanitasi dasar yang memadai.

\section{Simpulan}

Penelitian ini menunjukkan perbedaan antara persepsi dan sikap dalam program pencegahan dan pemberantasan demam berdarah dengue antara daerah urban dan rural. Pencegahan penyakit demam berdarah dengue bukanlah hal yang hanya dapat dikerjakan oleh individu atau sekelompok masyarakat saja. Kerjasama antara individu, kelompok masyarakat, dan pemerintah menjadi kunci keberhasilan penanganannya.

\section{Ucapan Terima Kasih}

Ucapan terima kasih disampaikan kepada para kader di Tamansari Kota Bandung dan Ciparay Kabupaten Bandung yang telah banyak membantu kelancaran pengambilan data.

\section{Daftar Pustaka}

1. Miles MB, Huberman AM, Saldana J. Qualitative data analysis: a method sourcebook. Thousand Oak California: SAGE Publication; 2014. 
2. Mulligan K. Dengue and development: a critical political ecology. Hamilton: McMaster University; 2013.

3. Campbell-Lendrum D, Molyneux D. Ecosystems and vector-borne disease control. Dalam: Epstein P, Githeko A, Rabinovich J, Weinstein $\mathrm{P}$, penyunting. Ecosystems and human well-being: Policy Responses. Washington DC, USA: Island Press; 2005. hlm. 353-72.

4. WHO. Global strategy for dengue prevention and control 2012-2020. Geneva: World Health Organisation; 2012.

5. Nam VS, Kay B, Yen NT, Ryan P, Bektas A. Community mobilization, behaviour change and biological control in the prevention and control of dengue fever in Viet Nam. Dengue Bull. 2004;28S:57-61.

6. Pujiyanti A, Triratnawati A. Pengetahuan dan pengalaman ibu rumah tangga atas nyamuk demam berdarah dengue. Makara. 2011;15(1):6-14.

7. Ohba S-y, Kashima S, Matsubara H, Higa Y, Piyaseeli UKD, Yamamoto H, dkk. Mosquito breeding sites and people's knowledge of mosquitoes and mosquito borne diseases: a comparison of temporary housing and nondamaged village areas in Sri Lanka after the tsunami strike in 2004. Trop Med Health. 2010;38(2):81-6.

8. Arunachalam N, Tana S, Espino F, Kittayapong P, Abeyewickreme W, Wai KT, dkk. Eco-bio-social determinants of dengue vector breeding: a multifactorial study in urban and periurban Asia. Bull WHO. 2010;88:173-84.

9. Kemenkes. Profil Kesehatan Indonesia. Jakarta: Kementrian Kesehatan Republik Indonesia; 2012.

10. Kemenkes. Profil Kesehatan Indonesia 2013. Jakarta: Kementrian Kesehatan Republik Indonesia; 2013.

11. Duncombe J, Clements A, Hu W, Weinstein P, Ritchie S, Espino FE. Review: geographical information systems for dengue surveillance. Am J Trop Med Hygiene. 2012;86(5):753-5.

12. Danis-Lozano $\mathrm{R}$, Rodríguez $\mathrm{MH}$, Hernández-Avila M. Gender-related family head schooling and Aedes aegypti larval breeding risk in Southern Mexico. Salud Pública de México. 2002;44(3).

13. BPS. Bandung dalam angka. Bandung: BPS; 2012.

14. Dinas Kesehatan Kabupaten Bandung Barat. Laporan demam berdarah dengue. Bandung: DKK; 2014. 